\title{
ORIGINAL
}

\section{Inhibition of Sardine Flesh Lipoxygenase by a New Antioxidant from Aspergillus terreus}

\author{
Yukihiro ISHIKAWA*1, Tadayoshi ITO*2, and Kuo Hsiung LEE*3 \\ *1 College of Education, Tottori University \\ (4-101 Koyama-cho Minami, Tottori-shi, = 680 ) \\ *2 Institute for Fermentation, Osaka \\ (17-85 Juso-honmachi 2-chome, Yodogawa-ku, Osaka-shi, T532) \\ *3 School of Pharmacy, University of North Carolina at Chapel Hill \\ (Chapel Hill, NC 27599-7360, USA)
}

\begin{abstract}
A new antioxidant and potent lipoxygenase (LOX) inhibitor, NC3B, was isolated from the fungus Aspergillus terreus and identified as 1,3-dihydro-7-methyl-4,5,6-trihydroxy-isobenzofuran. Under weight gain method conditions with methyl linoleate as a substrate, NC3B was a stronger antioxidant than tocopherol (Toc) and acted as a weak Toc synergist during the autoxidation of methyl linoleate. NC3B significantly inhibited the oxidation of linoleic acid by sardine flesh LOX and caused reduction in oxygen uptake by the substrate.
\end{abstract}

Key words : antioxidant, lipoxygenase inhibitor, Aspergillus, microorganism

\section{Introduction}

Many antioxidants are being identified as anticarcinogens and are expected to function as internal defense agents ${ }^{1}$. The development of new types of antioxidants and synergists for tocopherol (Toc) should be beneficial since Toc is a highly useful natural antioxidant. Therefore, we have focused on identifying microbial antioxidants and Toc synergists ${ }^{2) ~ 3)}$, since microorganisms such as fungi, yeast, bacteria, and Streptomyces may produce many new antioxidant forms ${ }^{4}$.

While screening fungi for Toc synergists, we have isolated a new antioxidant (NC3B) from the culture broth of Aspergillus species. NC3B was found to act as a potent inhibitor for lipoxygenase (LOX) in sardine skin. Mohri et al. recently reported the presence of LOX with stereoselective activity from this source ${ }^{5}$. LOX can catalyze the formation of different classes of compounds associated with off-flavors (for example, the oxidation of certain unsaturated fatty acids containing a cis, cis-1,4-pentadiene structure), thus rendering fish such as sardine unacceptable in quality. Therefore, LOX inhibitors could potentially retard the deterioration of many foods. Many LOX inhibitors are known to be phenolic compounds ${ }^{6)} \sim 9$ ) and are expected to retard the development of odorous flavors from soybeans, fish, and other foods.

The present report deals with strain identification, structural determination of $\mathrm{NC} 3 \mathrm{~B}$, and its antioxidative and LOX-inhibiting activities.

\section{Experimental}

2.1 Isolation and cultivation of fungi

A soil sample was suspended in sterilized distilled water and poured onto a medium con- 
taining $2 \%$ malt extract, $2 \%$ glucose, $0.2 \%$ peptone, $0.1 \%$ yeast extract, $2 \%$ agar, and 100 ppm streptomycin sulfate. A fungus belonging to the Aspergillus species was transferred to a slant containing the above medium without streptomycin sulfate.

Large cultures of the isolated fungus ( $\mathrm{NC} 3$ ) for metabolite preparations were grown statically at $24^{\circ} \mathrm{C}$ for 3 weeks on a medium composed of $2 \%$ malt extract, $3 \%$ glucose, $0.3 \%$ peptone, and $0.1 \%$ yeast extract.

\section{$2 \cdot 2$ Weight gain method}

The weight gain method was performed as described in the previous paper ${ }^{2)}$. Methyl linoleate, which was passed through silica gel to remove peroxides, was used as a substrate, and Toc was a natural Toc mixture (Eisai Co.).

\section{$2 \cdot 3$ Lipoxygenase assay}

The flesh of fresh sardine (Sardinops melanosticta) was minced with iced $0.1 \mathrm{M}$ phosphate buffer $\left(\mathrm{pH} \mathrm{7.0)}\right.$ and centrifuged at $0^{\circ} \mathrm{C}$ at $5000 \mathrm{rpm}$ for $15 \mathrm{~min}$. The precipitate was further extracted with the same buffer and treated similarly. Both of the supernatants were combined, centrifuged at $10000 \mathrm{rpm}$ for $15 \mathrm{~min}$, and used for the crude enzyme solution.

Lipoxygenase activity was assayed by the oxygen absorption method using a YSI 5331 oxygen probe (Yellow Springs Inst., OH, USA) ${ }^{10}$ ). The probe (potential ; $0.8 \mathrm{~V}$ ) was fitted to a reaction vessel kept at $30^{\circ} \mathrm{C}$ by circulating temperature-controlled water in its jacket. The reaction was started by adding enzyme solution $(20 \mu \mathrm{L})$ to the mixture containing substrate (1.96 $\mathrm{mL} ; 5 \mathrm{mM}$ linoleic acid and $0.2 \%$ Tween 20 in $0.1 \mathrm{M}$ phosphate buffer, $\mathrm{pH} 7.0$ ) and inhibitor solutions $(20 \mu \mathrm{L})$.

\subsection{Instrumental analyses}

The melting point was taken on a Fisher-Johns melting point apparatus and is uncorrected. NMR spectra were recorded on a Bruker AC-300 NMR spectrometer with tetramethylsilane as an internal standard. Samples were dissolved in deuterated chloroform and dimethyl sulfoxide. Mass spectral analyses were done on a VG TRIO-1000 mass spectrometer at $70 \mathrm{eV}$ in the electron impact mode. IR spectrum was measured with a JASCO FT-IR 7000 spectrometer. Elemental analysis was performed on a Carlo Erba EA 1108 elemental analyzer.

\section{Results and Discussion}

\subsection{Strain identification}

For the morphological investigation of the strain (NC 3), it was grown on malt extract agar (Nissui Seiyaku), potato dextrose agar (Difco Lab.), and Czapek Dox agar (Nissui Seiyaku) plates at $24^{\circ} \mathrm{C}$ for 2 weeks.

Microscopic observation of the strain showed features characteristic of Aspergillus species, and its description is as follows :

Colonies on malt extract agar, potato dextrose agar, and Czapek Dox agar attained diameters of $45 \sim 50 \mathrm{~mm}, 60 \sim 64 \mathrm{~mm}$, and $45 \sim 50 \mathrm{~mm}$, respectively ; typically velvety with no color on all agars ; colony reverse colorless ; conidial heads long, columnar ; conidiophores smooth, colorless ; vesicles hemispherical, domelike ; sterigmata in two series ; conidia globose, smooth ; globose to ovate hyaline cells produced on the vegetative mycelium. These results indicate that the strain is Aspergillus terreus ${ }^{11)}$.

\section{$3 \cdot 2$ Isolation of a metabolite and its identification}

The NC 3 strain fungus was cultured statically in medium (12 L). The culture broth was extracted with ethyl acetate, and the extract was concentrated to give a precipitate $(2.3 \mathrm{~g})$. The precipitate was suspended in ethyl acetate and mixed with Celite 545 ( 5 times by weight). After drying, the mixture was packed in a column and eluted with a $n$-hexane/ethyl acetate solvent system.

Upon spraying with Emmerie-Engel's (E-E) reagent (0.25\% 2,2-dipyridyl/0.1\% ferric chloride ethanol solution), a strong greenish-brown spot was attained at an $R_{f}$ value of 0.3 
<smiles>Cc1c(O)c(O)c(O)c2c1COC2</smiles>

Fig. 1 Structure of NC3B.

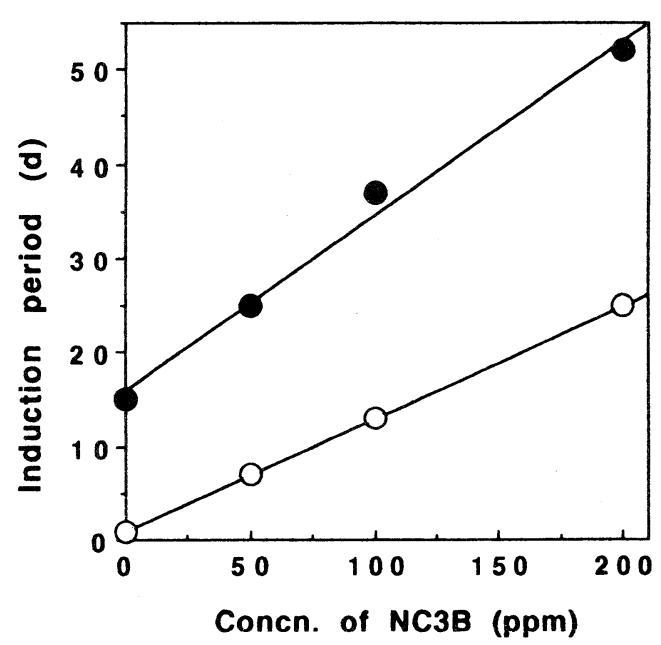

Fig. 2 Antioxidative Activity of NC3B and Its Synergism with Tocopherol During the Autoxidation of Methyl Linoleate under Weight Gain Method Conditions at $50^{\circ} \mathrm{C}$.

$\mathrm{O}$ : NC3B alone, : NC3B+Toc $(0.04 \%)$.

on a TLC plate (precoated Kieselgel $60, \mathrm{~F}_{254}$, Merck, benzene/ethyl formate/formic acid (5 : $4: 1)]$. At $254 \mathrm{~nm}$, this compound absorbed light strongly. The E-E reagent-positive fractions were applied to a Sephadex LH-20 column ; elution with chloroform/methanol (1: 1) removed most pigments. For further purificaion, the positive fractions were applied on a Sphadex LH-20 column equilibrated with $n$-hexane/chloroform/methanol $(2: 2: 1)$ to give a white powder (NC3B, $40 \mathrm{mg})$.

The physical and spectral properties of NC3B are as follows : mp 205 207 ${ }^{\circ} \mathrm{C}$. Anal. Found: $\mathrm{C}, 58.10 ; \mathrm{H}, 5.91 \%$, Calcd. for $\mathrm{C}_{9} \mathrm{H}_{10} \mathrm{O}_{4}: \mathrm{C}, 59.33 ; \mathrm{H}, 5.53 \%$. MS $\mathrm{m} / z: 182\left(\mathrm{M}^{+}\right), 167,153 .{ }^{1} \mathrm{H}^{-}$

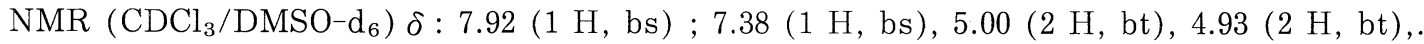
$3.58(1 \mathrm{H}, \mathrm{bs}), 2.00(3 \mathrm{H}, \mathrm{s}) .{ }^{13} \mathrm{C}-\mathrm{NMR}\left(\mathrm{CDCl}_{3} / \mathrm{DMSO}^{\left.-\mathrm{d}_{6}\right)} \delta: 143.6,137.3,131.6,129.1,115.9\right.$, 108.5, 72.9, 72.0, 11.9. IR (KBr) $\nu\left(\mathrm{cm}^{-1}\right): 3432,3346,3160,2866,1636,1516,1483,1390,1317$, $1106,1048,946,893$.

The peak at $\delta 4.93$ was broader than that as $\delta 5.00$ indicating coupling of the former peak with the adjacent methyl group. The presence of two methylene proton peaks suggested that $\mathrm{NC} 3 \mathrm{~B}$ is asymmetric.

The ${ }^{13} \mathrm{C}-\mathrm{NMR}$ and DEPT spectra revealed the presence of six olefinic carbons $(\delta 143.6$, $137.3,131.6,129.1,115.9,108.5)$, indicative of a substituted benzene ring. The DEPT spectrum showed that the peak at $\delta 11.9$ is due to an aromatic methyl group and the peaks at $\delta$ 72.9 and 72.0 are due to methylene groups.

Acetylation of NC3B with acetic anhydride/pyridine gave the triacetyl derivative. $\mathrm{MS} \mathrm{m} / \mathrm{z}$ : 


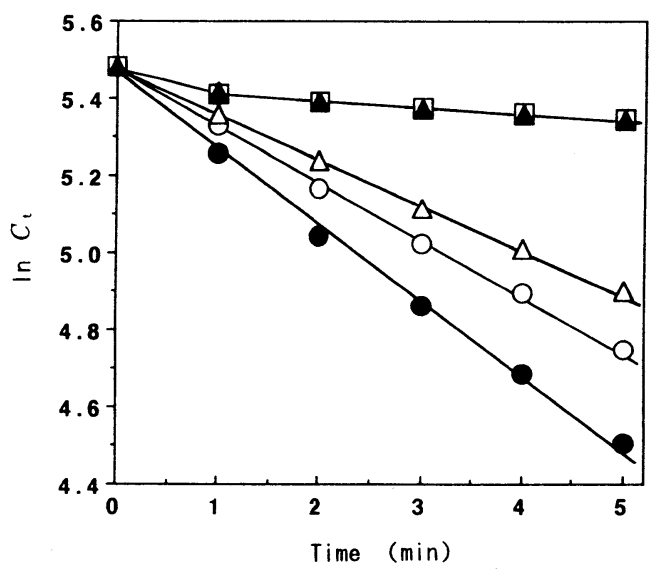

Fig. 3 Inhibitory Effect of NC3B on Sardine Lipoxygenase.

: control, $\bigcirc: 1 \mu \mathrm{g}, \triangle: 2 \mu \mathrm{g}, \square: 4 \mu \mathrm{g}, \boldsymbol{\Delta}: 10 \mu \mathrm{g}$.

ln $C_{t}$ shown the natural logarithm of oxygen concentration after time $t$.

$308\left(\mathrm{M}^{+}\right), 280,265,224,182,43 .{ }^{1} \mathrm{H}-\mathrm{NMR}\left(\mathrm{CDCl}_{3}\right) \delta: 5.09(2 \mathrm{H}, \mathrm{t}), 5.03(2 \mathrm{H}, \mathrm{t}), 2.32(3 \mathrm{H}, \mathrm{s})$, $2.29(3 \mathrm{H}, \mathrm{s}), 2.25(3 \mathrm{H}, 3), 2.05(3 \mathrm{H}, \mathrm{s})$. This result shows the presence of three free hydroxy groups.

The C-H COSY spectrum showed that two proton signals $(\delta 5.00,4.93)$ had cross peaks with $\mathrm{C}-3$ and $\mathrm{C}-1$, respectively. In the long range $\mathrm{C}-\mathrm{H}$ COSY spectrum, cross peaks were observed between the carbon at $\delta 129.1$ and protons at $\delta 2.00$ and at $\delta 4.93$. The methyl protons had cross peaks with carbons at $\delta 143.6,129.1$, and 108.5.

From the above data, NC3B was determined as 1,3-dihydro-7-methyl-4,5,6-trihydroxyisobenzofuran, and its structure is shown in Fig. 1. Naito and Kaneko ${ }^{12}$ ) have isolated a phenolic reductone, 1,3-dihydro-5-methyl-4,6,7-trihydroxyisobenzofuran, from Aspergillus terreus, which is a positional isomer of NC3B. The melting points are quite different between our $\left(205 \sim 207^{\circ} \mathrm{C}\right)$ and their $\left(122 \sim 125^{\circ} \mathrm{C}\right)$ metabolites.

\section{$3 \cdot 3$ Antioxidative a activity}

The antioxidant activity of NC3B and its synergism with Toc $(0.04 \%)$ were investigated by using weight gain method conditions with methyl linoleate as a substrate. Figure 2 shows that NC3B had slightly stronger activity than Toc, and this aciivity increased linearly with increasing concentration. $\mathrm{NC} 3 \mathrm{~B}$ also acted as a moderate Toc synergist.

\subsection{Lipoxygenase inhibition}

Figure 3 shows the plots of oxygen concentration $v s$. time during oxidation of linoleic acid by sardine flesh crude enzyme extract in the presence or the absence of NC3B. The rate of oxygen uptake without $\mathrm{NC3B}$ was very rapid. However, the subsequent addition of NC3B caused a linear reduction in oxygen uptake with increasing concentration. NC3B strongly inhibited sardine LOX when present at more than $4 \mu \mathrm{g}$.

Recently, other LOX inhibitors of microbial origin have been found. Flavoglaucin and its derivatives from Eurotium species ${ }^{13)}$ remarkably inhibited sardine LOX to retard the development of off-flavor (unpublished), and Streptomyces species produced a LOX inhibitor that acts on soybean LOX and human $5-\mathrm{LOX}^{9}$. Since LOX inhibitors do not always show activity in LOX of different origins such as human, plant, or fish ${ }^{14)}$, enzyme origin should be accounted for in screening for potent LOX inhibitors.

(Received May 1, 1996 ; Accepted Sep. 4, 1996) 


\section{References}

1) K. Fukuzawa, "Free Radicals in Clinical Medicine", Nihon-Igakukan (1988) Vol. 3, p. 41.

2) K. Morimoto, T. Yoshiwa, Y. Ishikawa, T. Hamasaki, J. Jpn. Oil Chem. Soc., 36, 10 (1987).

3) Y. Ishikawa, K. Morimoto, T. Sada, T. Fujiwara, J. Jpn. Oil Chem. Soc., 41, 1107 (1992).

4) L.R. Dugan, "Autoxidation in Food and Biological Systems", Plenum Press, New York (1980) p. 261.

5) S. Mohri, S-Y, Cho, Y. Endo, K. Fujimoto, J. Agric. Food Chem., 40, 573 (1992).

6) K. Yasumoto, A. Yamamoto, H. Mitsuda, Agric. Biol. Chem., 34, 1162 (1970).

7) D.L. King, B.P. Klein, J. Food Sci., 52, 220 (1987).

8) S. Imai, M. Morikiyo, K. Furihata, Y. Hayakawa, H. Seto, Agric. Biol. Chem., 54, 2367 (1990).

9) T. Komoda, Y. Morimitsu, H. Hirota, A. Hirota, Biosci. Biotech. Biochem., 59, 924 (1995).

10) K. Fukuzawa, J. Terao, "Shishitu-Kasanka-Jikkennho", Hirokawa Pub., Tokyo (1990) p. 72.

11) K.B. Raper, D.I. Fennell, "The Genus Aspergillus", The Williams \& Wilkins, Baltimore (1965) p. 567.

12) S. Naito, Y. Kaneko, Tetrahedron Lett., 53, 4675 (1969).

13) Y. Ishikawa, K. Morimoto, T. Hamasaki, J. Am. Oil Chem. Soc., 61, 1864 (1984).

14) S-Y. Cho, Y. Endo, K. Fujimoto, T. Kaneda, Nippon Suisan Gakkaishi, 55, 545 (1989). 


\title{
日本油化学会誌本号掲載 論文要旨
}

\section{[総説 $]$}

\section{LB 膜の構造・機能制御}

\author{
松 本 睦 良 \\ 物質工学工業技術研究所 (
}

LB 膜の構造と機能を 3 種類の方法を用いて制御した。最初の方法では, トリガー分子としてへキサトリアコン 夕ンを用い, 非両親媒性ポルフィリン分子の配向と会合体構造を制御した。トリガー分子なしでは, ポルフィリン は基板に対して傾いた配向をとるのに対し，トリガー分子の存在下ではポルフィリンは基板に対してほぼ垂直の配 向をとった。2 番目の方法は, ポリイオン錯体形成を利用するものである。ポリカチオン種により, アゾベンゼン LB 膜の構造と光異性化反応を制御できることが分かった。最後の方法では, アゾベンゼンの光異性化反応を利用 した。光異性化反応は LB 膜の構造の変化をもたらし, 導電率のスイッチングと共存するシアニン色素の会合体の 変化をもたらした。

(連絡者: 松本睦良) Vol. 45, No. 12, 1311 (1996).

\section{[報文Ａspergillus terreus の生産する新規酸化防止剂と そのイワシ肉リポキシゲナーゼ阻害活性}

\author{
石川行 弘*1 ・伊 藤 忠 義 ${ }^{* 2} \cdot$ Kuo Hsiung LEE*3 \\ *1 鳥取大学教育学部 ( 680 鳥取市湖山町南 4-101) \\ $* 2$ (財) 発醭研究所 (下532 大阪市淀川区十三本町 2-17-85) \\ *3 ノースカロライナ大学チャペルヒル校薬学部 (Chapel Hill, NC 27599-7360, USA)
}

新規の酸化防止剂及び優れたリポキシゲナーゼ (LOX) 阻害剤である NC3B を Aspergillus terreus の培養沪 液から単離し, 1,3-dihydro-7-methyl-4,5,6-trihydroxyisobenzofuran と同定した。リノール酸メチルを基質 とする重量法条件において, NC3B の抗酸化性はトコフェロールよりは強いが, 相乗効果は弱かった。NC3B は, LOXによるリノール酸の酸化を顕著に阻害し，酸素消費量を減少させることが分かった。

(連絡者:石川行弘) Vol. 45, No. 12, 1321 (1996).

\section{[報文］高度不飽和油脂に対するスペルミンの酸化防止相乗作用}

\author{
小川 博史・辻宏明*・瀬戸 明*・原節子・戸谷洋一郎 \\ 成蹊大学工学部 (₹180 東京都武蔵野市吉祥寺北町 3-3-1) \\ * 日清製油株式会社研究所 ( 7239 神奈川県横須賀市神明町 1)
}

自然界に存在する代表的なポリアミンの 1 種であるスペルミンの酸化防止効果およびトコフェロール (Toc) に 対する相乗効果について, 高度不飽和油脂を自動酸化基質として検討した。その結果, 自動酸化期間中のスペルミ ンを添加した実験群と無添加の対照群の PV と CV の上昇に差が観察されず，スペルミンは酸化防止作用を持た ないことが判明した。

また, 精製魚油に Toc を添加した実験群の PV 上昇がスペルミン添加量に依存して効果的に制御されたことか ら，スペルミンはTocに対して強い相乗効果を示すことが確認された。 